Reprinted from Agronomy Journal

Vol. 80 , No. 3

Late Fall Fertilization of Kentucky Bluegrass

D. J. Wehner, J. E. Haley, and D. L. Martin 


\title{
Late Fall Fertilization of Kentucky Bluegrass
}

\author{
D. J. Wehner, * J. E. Haley, and D. L. Martin
}

\section{ABSTRACT}

Many turfgrass managers apply a portion of the total yearly $N$ to cool-season turfgrasses in the late fall (November). The purpose of this field study was to compare fertilization programs with and without $\mathbf{N}$ applications in November using both slow-release and soluble $N$ sources. Turfs of two different cultivars of Kentucky bluegrass (Poa pratensis L. cv. Baron and cv. Newport) growing on a Flanagan silt logm (fine, montmorillonitic, mesic Aquic Argiudoll) received 10 fertilization programs utilizing urea, isobutylidene diurea (IBDU), or sulfur-coated urea (SCU). Urea was applied four times per year with either a spring application or a late-fall application combined with applications in early $J u n e$, mid-July, and early September (171-196 kg N ha-1 yr ${ }^{-1}$ ). For IBDU and SCU, application dates and $\mathrm{N}$ rates $\left(\mathrm{kg} \mathrm{ha}^{-1}\right)$ consisted of June $98+$ September 98 , June 98 + November 98 , and June $49+$ September $49+$ November 74. The turfs were rated for color for $3 \mathrm{yr}$, and clipping weights were determined weekly for the final $2 \mathrm{yr}$ of the study. Results were generally similar for both cultivars, except fewer significant differences in spring color ratings were found on Newport. An application of urea in November, without a subsequent spring fertilization, resulted in higher turf color ratings in the early spring but lower turf color ratings in May and June, compared to turf receiving a spring fertilization. Results indicate that a late-fall application of urea may not eliminate the need for spring fertilization but may allow a reduction in the amount of $\mathbf{N}$ applied in spring. Turfs fertilized with SCU in November received higher color ratings in the spring than did turf fertilized with SCU in September. With IBDU, the June + September program resulted in the highest number of ratings with acceptable turf color. November IBDU applications did
\end{abstract}

not result in higher color ratings in the spring and resulted in inefficient use of the $\mathbf{N}$ applied.

Additional Index Words: Isobutylidene diurea, Sulfur-coated urea, Urea, 'Baron', 'Newport', Nitrogen, Turfgrass, Poa pratensis L.

$T^{\mathrm{s}}$ HE PRACTICE of applying a portion of the total yearly $\mathrm{N}$ to cool-season turfgrasses in late fall (November) has gained acceptance by turfgrass managers in Illinois and surrounding states. The major benefits of a late-fall $\mathrm{N}$ fertilization are improved (darker green) turfgrass color in early spring and more extensive root growth. Koski and Street (1985), using a rhizotron in Ohio, have reported that root growth is more extensive because the improved spring color resulting from late-fall fertilization reduces the need for an early spring $N$ application. Spring $N$ fertilization can reduce the root growth of cool-season turfgrasses by promoting shoot growth.

Research on the use of late-fall $\mathrm{N}$ has been conducted in states with maritime (Ledeboer and Skogley,

Dep. of Horticulture, Univ. of Illinois, Urbana, IL 61801. Contribution from the Dep. of Horticulture, Univ. of Illinois, Urbana. This study was part of Project no. 65-267 of the Agric. Exp. Stn., Univ, of Illinois, Urbana. Received 18 May 1987. "Corresponding author.

Published in Agron. J. 80:466-471 (1988). 
1973; Wilkinson and Duff 1972) or transitional climates (Hanson and Juska, 1961; Powell et al., 1967a, 1967b) where it was possible to maintain green turfgrass color almost year-round. Initial hesitancy to use late-fall $\mathrm{N}$ applications in the Midwest was based on fear of reduced winter hardiness (Beard, 1973; Carroll and Welton, 1939). However, field observations have indicated that winter injury does not usually increase with the use of late-fall $\mathrm{N}$ fertilization.

The development of new sources of $\mathrm{N}$ and the growth of the professional lawn-care industry have generated the need for more information on the practice of late-fall $\mathrm{N}$ fertilization.

Sulfur-coated urea (SCU) and isobutylidene diurea (IBDU) are two popular slow-release $\mathrm{N}$ sources used for turfgrass fertilization. Evaluations of these fertilizers on Kentucky bluegrass (Wilkinson, 1977; Waddington et al., 1977; Hummel and Waddington, 1984; Moberg et al., 1970) have not involved a late-fall application. Volk and Horn (1975) made large (200 or $300 \mathrm{~kg} \mathrm{~N} \mathrm{ha}{ }^{-1}$ ) single applications of IBDU and an experimental application of SCU ( $9 \%$ dissolution rate) to bermudagrass [Cynodon dactylon (L.) Pers.] in Florida. They reported that the IBDU did not show the cold weather depression of latent- $\mathrm{N}$ release exhibited by SCU. However, these results must be viewed with the knowledge that the currently available commercial SCU products for turfgrass have dissolution rates of 30 to $35 \%$. Moberg et al. (1970) found better cool-weather response with IBDU than with ureaformaldehyde fertilizers.

Hummel and Waddington (1984), in evaluating the use of SCU with different dissolution rates, reported that the most uniform results were obtained with two or three split applications of $245 \mathrm{~kg} \mathrm{~N} \mathrm{ha}^{-1}$ from fertilizers with dissolution rates of 25 and $30 \%$. Wilkinson (1977) evaluated multiple rates and timing of application of IBDU. He reported that two applications of IBDU were required for the most uniform turf-quality response.

The rate of release of $\mathrm{N}$ from IBDU is affected by
$\mathrm{pH}$, soil temperature, soil moisture, and particle size (Hamamoto, 1966). Dissolution of the fertilizer particle is followed by hydrolysis of the molecule to release urea and isobutyraldehyde. Hughes (1976) indicated that, in alkaline soils, delayed plant response to IBDU fertilization can occur and that particle size greatly influences the release rate of $\mathrm{N}$. Lunt and Clark (1969), working with temperatures of 10 and $27^{\circ} \mathrm{C}$, reported that soil temperature did not have a major effect on the conversion of IBDU-N to soluble forms.

Allen et al. (1971), working with several experimental SCU sources, found that $\mathrm{N}$ release from SCU was affected by coating weight, placement of the fertilizer particle (surface vs. incorporated into soil), and temperature. Dissolution of the granules layered in the soil was relatively fast at 20 or $30^{\circ} \mathrm{C}$ but relatively slow at $10^{\circ} \mathrm{C}$.

The lawn-care industry relies on the use of urea for turfgrass fertilization because of its low cost, solubility for tank mixing, and relatively low salt index compared to other quick-release $\mathrm{N}$ sources. Information is needed by the lawn-care industry to determine the effectiveness of late-fall fertilization in altering the need for spring applications of N. Spangenberg et al. (1986) evaluated fertilization programs similar to those used by the lawn-care companies. Their treatments, however, did not involve an $\mathrm{N}$ application in November.

The purpose of this research was to evaluate fertilization programs with or without a late-fall application of IBDU, SCU, and urea in comparison to programs with a September application of $\mathrm{N}$.

\section{MATERIALS AND METHODS}

This study was initiated on 7 Sept. 1982 and concluded on 1 Nov. 1985. Adjacent pure stands of 'Newport' and 'Baron' Kentucky bluegrass growing on a Flanagan silt loam were used for this research. Plots were established for each cultivar, with an individual plot size of 0.9 by $3.1 \mathrm{~m}$ and three replications in a randomized complete-block design. The cultivars were established in June 1982. An application of $49 \mathrm{~kg} \mathrm{~N} \mathrm{ha}^{-1}$ from 10-4.4-8.3 (N-P-K) was made at es-

Table 1. Application timings and $\mathrm{N}$ rates for fertilization programs and number of ratings when treatment resulted in acceptable (rating $\geq 7.0)$ color. Color was rated on a scale of 1 to 9 with $1=$ yellow turfgrass color and $9=$ dark green color. Color was rated on 64 dates over 3 yr.

\begin{tabular}{|c|c|c|c|c|c|c|c|}
\hline \multirow{3}{*}{$\begin{array}{l}\text { Treatment number } \\
\text { (designation) }\end{array}$} & \multicolumn{5}{|c|}{ Application dates } & & \\
\hline & \multirow{2}{*}{$\begin{array}{r}5 \text { May } 83 \\
2 \text { May } 84 \\
26 \text { Apr. } 85\end{array}$} & \multirow{2}{*}{$\begin{array}{l}6 \text { June } 83 \\
6 \text { June } 84 \\
6 \text { June } 85\end{array}$} & \multirow{2}{*}{$\begin{array}{l}15 \text { July } 83 \\
17 \text { July } 84 \\
21 \text { July } 85\end{array}$} & \multirow{2}{*}{$\begin{array}{r}7 \text { Sept. } 82 \\
2 \text { Sept. } 83 \\
10 \text { Sept. } 84 \\
3 \text { Sept. } 85 \\
\end{array}$} & \multirow{2}{*}{$\begin{array}{r}1 \text { Nov. } 82 \\
10 \text { Nov. } 83 \\
2 \text { Nov. } 84\end{array}$} & \multicolumn{2}{|c|}{$\begin{array}{l}\text { Number of ratings when } \\
\text { turfgrass color was acceptable }\end{array}$} \\
\hline & & & & & & Baron & Newport \\
\hline & & 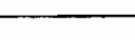 & $-\mathrm{kg} N \mathrm{ha}^{-1}$ & & $\overline{ }$ & & \\
\hline \multicolumn{8}{|l|}{ Urea $(46-0-0)$ programs } \\
\hline $\begin{array}{l}\text { 1 Spring urea (SU) } \\
2 \text { Late fall urea (FU) } \\
3 \text { Urea + SCU (U + SCU) } \\
4 \text { Low spring urea (LSU) }\end{array}$ & $\begin{array}{r}61 \\
0 \\
0 \\
25\end{array}$ & $\begin{array}{l}49 \\
49 \\
49 \\
49\end{array}$ & $\begin{array}{l}37 \\
37 \\
37 \\
37\end{array}$ & $\begin{array}{l}49 \\
49 \\
49 \\
61\end{array}$ & $\begin{array}{l}0 \\
61 \\
61 \text { (SCU) } \\
0\end{array}$ & $\begin{array}{l}48 \\
39 \\
41 \\
46\end{array}$ & $\begin{array}{l}45 \\
39 \\
40 \\
40\end{array}$ \\
\hline \multicolumn{8}{|l|}{ SCU (32-0.0) programs } \\
\hline $\begin{array}{l}5 \text { Standard SCU (SCU) } \\
6 \text { Late fall SCU (FSCU) } \\
7 \text { Low rate SCU (LSCU) }\end{array}$ & & $\begin{array}{l}98 \\
98 \\
49\end{array}$ & & 49 & $\begin{array}{l}98 \\
74\end{array}$ & $\begin{array}{l}37 \\
36 \\
32\end{array}$ & $\begin{array}{l}38 \\
36 \\
33\end{array}$ \\
\hline \multicolumn{8}{|l|}{ IBDU $(31-0.0)$ programs } \\
\hline $\begin{array}{l}8 \text { Standard IBDU (IBDU) } \\
9 \text { Late fall IBDU (FIBDU) } \\
10 \text { Low rate IBDU (LIBDU) } \\
11 \text { Control }\end{array}$ & 0 & $\begin{array}{r}98 \\
98 \\
49 \\
0\end{array}$ & 0 & $\begin{array}{r}49 \\
0\end{array}$ & $\begin{array}{r}98 \\
74 \\
0\end{array}$ & $\begin{array}{r}40 \\
32 \\
26 \\
0\end{array}$ & $\begin{array}{r}38 \\
29 \\
27 \\
0\end{array}$ \\
\hline
\end{tabular}


tablishment. The plots were irrigated as necessary to prevent drought stress and mowed one time per week at a height of $5.0 \mathrm{~cm}$ with clippings collected.

Fertilizer treatments and dates of application are listed in Table 1. The fertilizers used in this research consisted of urea (46-0-0), IBDU (31-0-0, fine grade; Estech General Chemicals Corp., Fairview Heights, IL), and SCU (32-0-0; Canadian Industries Ltd.,). All treatments were applied by hand. The treatments utilizing urea were part of the North Central Regional Project 10 cooperative study on the latefall fertilization of Kentucky bluegrass. Weather data for the growing seasons during 1983 to 1985 are presented in Fig. 1.

During 1983, color ratings were taken on a monthly basis throughout the growing season, using a scale of 1 to 9 with $1=$ yellow color and $9=$ dark green color. During 1984 and 1985 , color ratings and clipping weights were taken on a weekly basis during the growing season. Clippings were collected from a 0.53 -m-wide strip through the center of each plot, and the fresh weight of the clippings was determined.

Color ratings and clipping weights for each date were subjected to an analysis of variance. Each cultivar was analysed separately. Means were compared using single-degree-offreedom contrasts.

\section{RESULTS AND DISCUSSION}

The fertilization programs resulted in significant differences in turfgrass color ratings and clipping weights for both cultivars of Kentucky bluegrass. The significant differences between treatments are summarized in Table 2 . The fertilization programs resulted in acceptable turf color (rating $\geq 7.0$ ) on 26 (IBDU; three applications, $269 \mathrm{~kg} \mathrm{~N} \mathrm{ha}^{-1}$ ) to 48 (urea, spring application program) of the 64 rating dates (Table 1). The general trends in color and clipping weight on the two cultivars were similar; however, there were fewer significant differences between treatments on the Newport Kentucky bluegrass compared to the Baron Kentucky bluegrass turf (Table 2). Newport resumed growth earlier in the spring than did Baron. This characteristic reduced the effect of the fetilization treatments on the early spring color of Newport. Unless indicated, treatment effects over both cultivars will be discussed for the remainder of the paper.

\section{Fertilization with Urea}

The first four treatments differed in the timing and rate of $\mathrm{N}$ from urea applications. Spring urea (SU, treatment 1) resulted in the largest number of weeks with acceptable turfgrass color ratings of any treatment (48 weeks; Table 2). Color ratings on SU fertilized turf were significantly higher than ratings from late-fall urea fertilized turf (FU, treatment 2) approximately twice as often as ratings from FU treated turf were significantly higher than those from SU treated turf. The SU treated turf received higher color ratings during May and June, while the FU treated turf was rated higher in the early spring (Fig. 2). When the amount of $\mathrm{N}$ from urea in the spring was reduced (low spring urea, LSU, treatment 4), the same trends were apparent when compared to $\mathrm{FU}$; lower color ratings in the early spring with LSU but higher color ratings
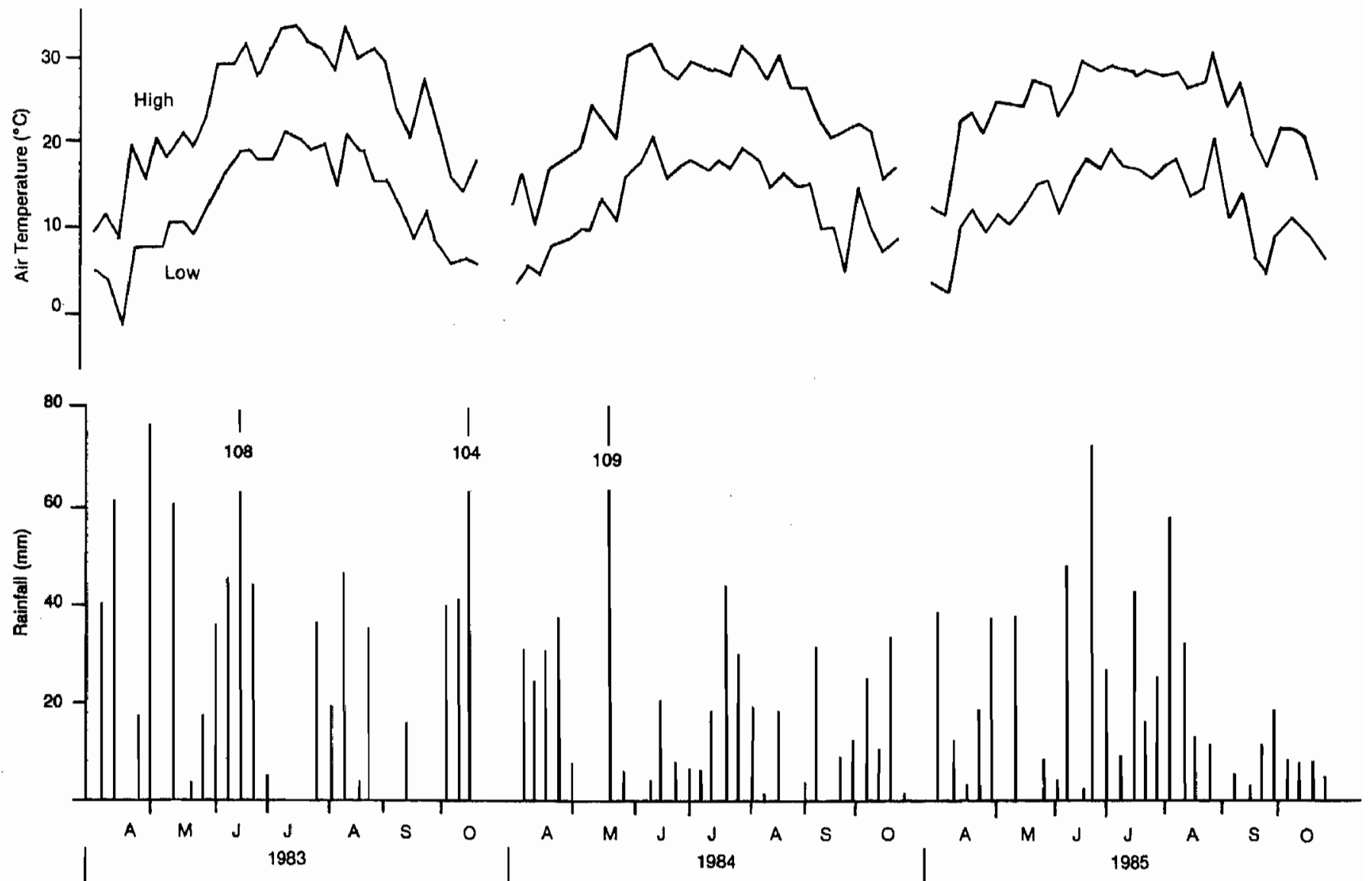

Fig. 1. Weekly average high and low air temperature and rainfall for the 1983 through 1985 growing seasons. 
in May and June (Fig. 2). Replacing the urea $\mathrm{N}$ in the late fall with $\mathrm{N}$ from SCU (treatment 3, U+SCU) did not improve the color of the turf during May and June (data not shown). There were few significant differences between the FU and U+SCU treatments. The differences that did occur were during random periods. Thus, there was no significant benefit in using SCU in place of the less-expensive urea in the late fall.

The trends apparent from the clipping weights for the four urea-based treatments paralleled the trends from the color rating data, with the exception that the growth rate as indicated by clipping weights of LSU treated turf more closely matched that of the FU treated turf than would be expected from the color rating differences (Table 2). Apparently, the $25 \mathrm{~kg} \mathrm{~N}$ $\mathrm{ha}^{-1}$ applied in spring was enough to enhance the color of the turf during May and June but did not greatly affect the growth rate.

The results of the four urea treatments indicate that the use of a late-fall urea application enhances spring color. However, a late-fall urea application may not eliminate the need for spring $\mathrm{N}$ fertilization under all circumstances. When turf color in May and June is important, it may be necessary to make a modest $\mathrm{N}$ application in the spring.

\section{Fertilization with SCU}

A standard University of Illinois recommendation for using SCU on cool-season turfgrasses involves an application of $98 \mathrm{~kg} \mathrm{~N} \mathrm{ha}^{-1}$ in June and September (treatment 5 , referred to as SCU program). The purpose of treatments 6 and 7, respectively, was to determine the effect of shifting the September application to November (late-fall SCU, FSCU, treatment 6) and the effect of lowering the $\mathrm{N}$ rate but using three applications (low rate of SCU, LSCU program). The three fertilization programs resulted in acceptable turfgrass color on 32 to 38 of the rating dates. The shift of the $98 \mathrm{~kg} \mathrm{~N} \mathrm{ha}^{-1}$ application from September
Table 2. Summarization of the frequency of significant differences between treatments on Baron and Newport Kentucky bluegrass as determined by single-degree-of-freedom contrasts. Clipping weights (yield) were determined on 50 dates; color rated on 64 dates. Color was rated on a scale of 1 to 9 with $1=$ yellow turfgrass color and $9=$ dark green turfgrass color.

\begin{tabular}{|c|c|c|c|c|c|c|c|c|}
\hline \multirow{2}{*}{$\begin{array}{l}\text { Treat- } \\
\text { ment I }\end{array}$} & \multirow{2}{*}{$\begin{array}{c}\text { Treat- } \\
\text { ment II }\end{array}$} & & \multicolumn{3}{|c|}{ Baron } & \multicolumn{3}{|c|}{ Newport } \\
\hline & & & $\mathrm{I}>\mathrm{II}^{*}$ & $\mathrm{II}>\mathrm{I}^{*}$ & $\mathrm{I}=\mathrm{II}$ & $I>I I *$ & $\mathrm{II}>\mathrm{I}^{*}$ & $I=I I$ \\
\hline \multicolumn{9}{|c|}{ Urea (46-0.0) grograms } \\
\hline SU & FU & color & $\begin{array}{r}21 \\
8\end{array}$ & 10 & $\begin{array}{l}33 \\
39\end{array}$ & 19 & 7 & 38 \\
\hline FU & $\mathrm{U}+\mathrm{SCU}$ & color & 2 & 6 & 56 & 1 & 8 & 55 \\
\hline FU & LSU & $\begin{array}{l}\text { yield } \\
\text { color } \\
\text { yield }\end{array}$ & $\begin{array}{l}0 \\
9 \\
7\end{array}$ & $\begin{array}{r}3 \\
16 \\
4\end{array}$ & $\begin{array}{l}47 \\
39 \\
39\end{array}$ & $\begin{array}{l}0 \\
8 \\
4\end{array}$ & $\begin{array}{r}2 \\
16 \\
6\end{array}$ & $\begin{array}{l}48 \\
40 \\
40\end{array}$ \\
\hline \multicolumn{9}{|c|}{ SCU $(32-0-0)$ programs } \\
\hline $\operatorname{scU}$ & FSCU & $\begin{array}{l}\text { color } \\
\text { yield }\end{array}$ & $\begin{array}{l}15 \\
13\end{array}$ & $\begin{array}{l}21 \\
24\end{array}$ & $\begin{array}{l}28 \\
13\end{array}$ & $\begin{array}{l}15 \\
13\end{array}$ & $\begin{array}{r}14 \\
8\end{array}$ & $\begin{array}{l}35 \\
29\end{array}$ \\
\hline $\mathrm{SCU}$ & LSCU & $\begin{array}{l}\text { color } \\
\text { yield }\end{array}$ & $\begin{array}{l}26 \\
26\end{array}$ & $\begin{array}{r}14 \\
9\end{array}$ & $\begin{array}{l}24 \\
15\end{array}$ & $\begin{array}{l}30 \\
29\end{array}$ & $\begin{array}{l}8 \\
5\end{array}$ & $\begin{array}{l}26 \\
16\end{array}$ \\
\hline \multicolumn{9}{|c|}{$\underline{\text { IBDU }(31-0-0) \text { prograrns }}$} \\
\hline IBDU & FIBDU & $\begin{array}{l}\text { color } \\
\text { yield }\end{array}$ & $\begin{array}{l}19 \\
20\end{array}$ & $\begin{array}{l}2 \\
0\end{array}$ & $\begin{array}{l}43 \\
30\end{array}$ & $\begin{array}{r}9 \\
10\end{array}$ & $\begin{array}{l}4 \\
1\end{array}$ & $\begin{array}{l}51 \\
39\end{array}$ \\
\hline IBDU & LIBDU & $\begin{array}{l}\text { color } \\
\text { yield }\end{array}$ & $\begin{array}{l}22 \\
31\end{array}$ & $\begin{array}{l}1 \\
8\end{array}$ & $\begin{array}{l}41 \\
11\end{array}$ & $\begin{array}{l}19 \\
21\end{array}$ & $\begin{array}{l}3 \\
0\end{array}$ & $\begin{array}{l}42 \\
29\end{array}$ \\
\hline \multicolumn{9}{|c|}{ Comparisons between fertilizer sources } \\
\hline FU & IBDU & color & 14 & 18 & 32 & 12 & 17 & 35 \\
\hline FU & SCU & $\begin{array}{l}\text { color } \\
\text { yield }\end{array}$ & $\begin{array}{r}14 \\
9\end{array}$ & $\begin{array}{l}17 \\
21\end{array}$ & $\begin{array}{l}34 \\
33 \\
20\end{array}$ & $\begin{array}{r}6 \\
9\end{array}$ & $\begin{array}{l}11 \\
20 \\
19\end{array}$ & $\begin{array}{l}38 \\
22\end{array}$ \\
\hline LIBDU & LSCU & $\begin{array}{l}\text { color } \\
\text { yield }\end{array}$ & 11 & $\begin{array}{l}17 \\
19\end{array}$ & $\begin{array}{l}36 \\
31\end{array}$ & $\begin{array}{l}8 \\
5\end{array}$ & $\begin{array}{r}17 \\
8\end{array}$ & $\begin{array}{l}39 \\
37\end{array}$ \\
\hline
\end{tabular}

$* P=0.05$.

to November resulted in significant differences in turfgrass color in both the spring and fall of the year, compared to the standard program. The FSCU treated turf received significantly higher color ratings in April, May, and part of June (Fig. 3), while the SCU treated turf received higher color ratings from mid-September to November. The LSCU program resulted in turf receiving higher color ratings in the spring (Fig. 3) but lower color ratings during the remainder of the year,

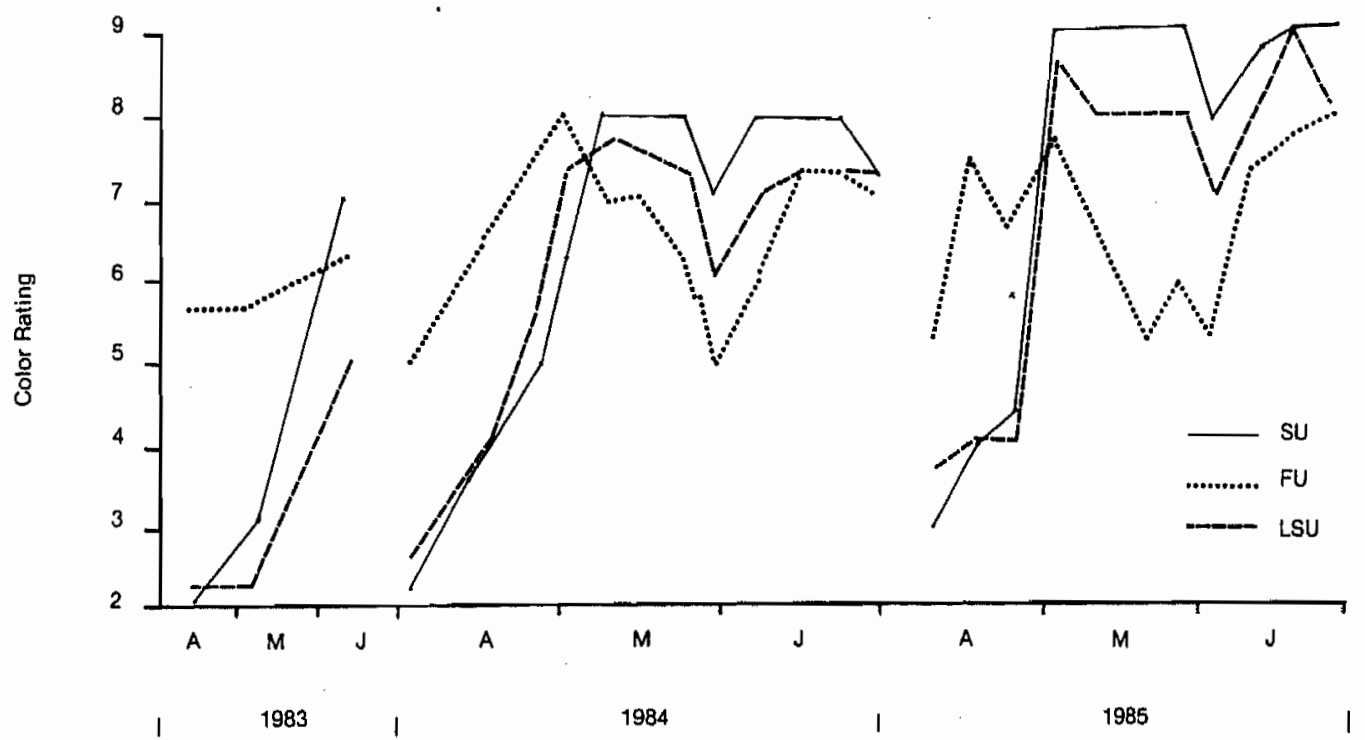

Fig. 2. April, May, and June color ratings for turf fertilized with spring urea (SU) and late-fall urea (FU) programs at $194 \mathrm{~kg} \mathrm{~N} \mathrm{ha}^{-1} \mathrm{yr}^{-1}$, and a low-rate spring urea (LSU) program at $171 \mathrm{~kg} \mathrm{~N} \mathrm{ha}^{-1} \mathrm{yr}^{-1}$. Color was rated on a 1 to 9 scale with $1=$ yellow turf and $9=$ dark green turf. 


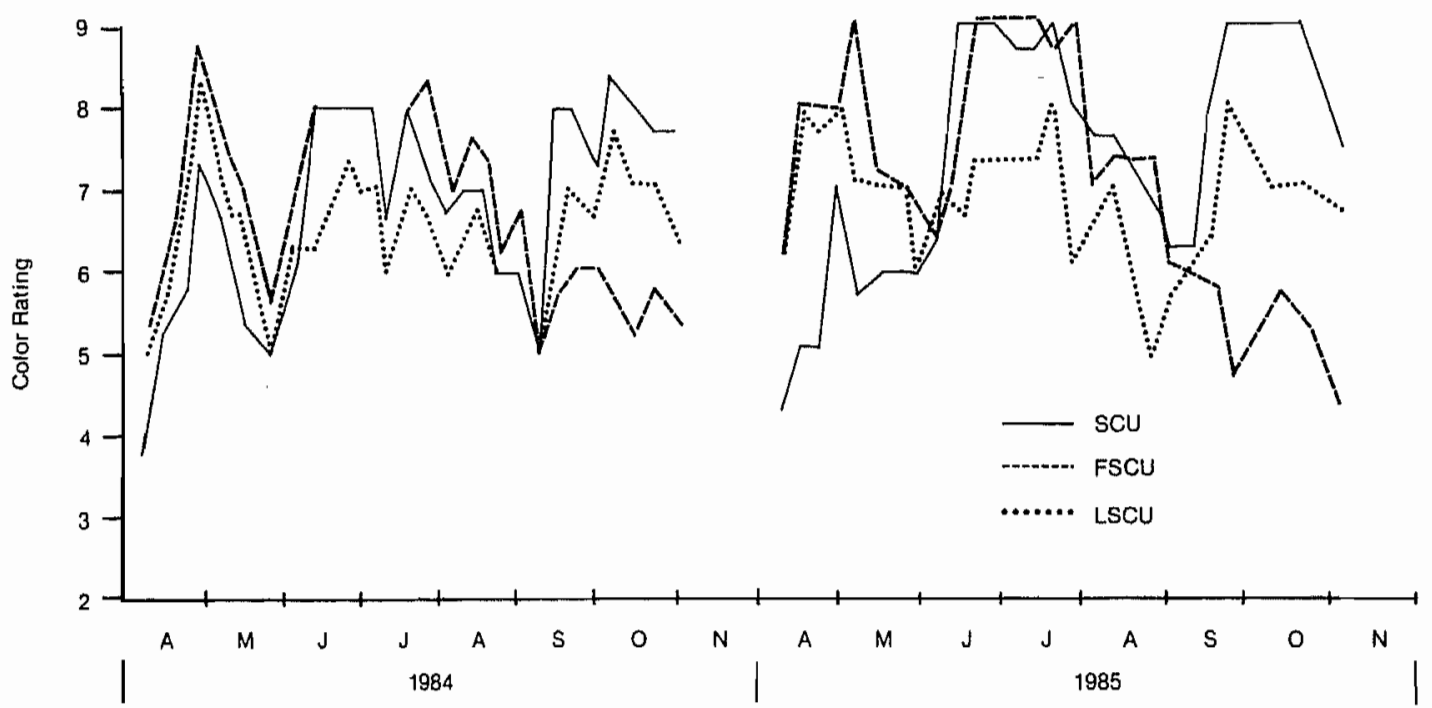

Fig. 3. Color ratings for 1984 and 1985 for Baron Kentucky bluegrass fertilized with June + September SCU applications (SCU), and June + November SCU applications (FSCU) at $196 \mathrm{~kg} \mathrm{~N}$ ha ' $\mathrm{yr}^{\prime}$ ', and turf fertilized with SCU in June + September + November (LSCU) at $171 \mathrm{~kg} \mathrm{~N} \mathrm{ha}{ }^{-1} \mathrm{yr}^{-1}$. Color was rated on a 1 to 9 scale with $1=$ yellow turf and $9=$ dark green turf.

compared to turf receiving the SCU program. The LSCU program appeared to be a viable alternative compared to the SCU and FSCU programs for managers wishing to reduce their yearly rate of $\mathrm{N}$ application using SCU.

The clipping weights for the Baron and Newport turfs differed when the SCU program was compared to the FSCU program (Table 2). For both cultivars, the SCU program resulted in significantly higher clipping weights on 13 occasions. However, for Baron, the FSCU treatment resulted in significantly higher clipping weights than did the SCU program on 24 dates, while for Newport, the FSCU treated turf had higher clipping weights than did the SCU treated turf on only eight dates. As mentioned earlier, Newport resumes growth earlier in the year than does Baron. This difference probably affected the response to fertilization treatments.

\section{Fertilization with IBDU}

Shifting the application of IBDU from September (treatment 8 , IBDU program) to November (treatment 9, FIBDU program) or reducing the rate of $\mathrm{N}$ from IBDU (treatment 10, LIBDU program) reduced the number of weeks when the turf received an acceptable color rating (Table 1). The differences in spring turfgrass color were minimal between turfs treated with the three IBDU programs (data not shown). With Newport, there were virtually no significant differences in early spring color resulting from IBDU programs. For Baron, turf color ratings from the standard IBDU program were significantly higher than color ratings from the FIBDU program the first two rating dates for 1984 and 1985 . The remainder of the significant differences between programs occurred in the summer and fall of the year.

The fact that neither the FIBDU or LIBDU program resulted in higher color ratings than the IBDU program in the spring, summer, or fall indicates that November applications of IBDU are inefficient. Dissolution of IBDU results in release of urea and iso- butyraldehyde. Since November-applied urea does influence turfgrass color the following spring, it appears that the slow rate of dissolution of IBDU must result in not enough $\mathrm{N}$ being released or converted to plantavailable forms prior to the onset of winter dormancy to significantly enhance spring color. Also, the continued dissolution of IBDU over the winter may result in a low level of residual $\mathrm{N}$ in the early spring.

Significant differences in clipping weights due to the three IBDU fertilization programs occurred more frequently on Baron than on Newport.

\section{Comparison between Fertilizer Sources}

Comparing the results of the late-fall program using urea (FU, treatment 2 ) versus a more expensive program of June and September applications of SCU (treatment 5) or IBDU (treatment 8 ) revealed that all three programs resulted in acceptable color ratings on 37 to 40 rating dates. On both cultivars, the FU program resulted in significantly higher color ratings in the early spring than the SCU program, while the SCU program resulted in significantly higher color ratings in June, July, and October. Compared to the IBDU program, the FU program resulted in significantly higher color ratings in June, while the IBDU program resulted in significantly higher color ratings in August and October.

The final comparison was made between the LSCU and LIBDU programs, which consisted of three applications at the lower $\mathrm{N}$ level $\left(171 \mathrm{~kg} \mathrm{~N} \mathrm{ha}^{-1} \mathrm{yr}^{-1}\right)$. The LSCU program resulted in significantly higher color ratings in June and July, while the LIBDU program resulted in significantly higher color ratings in August and September. The LSCU program resulted in a larger number of ratings where turfgrass color was acceptable compared to the LIBDU program.

\section{REFERENCES}

Allen, S.E., C.M. Hunt, and G.L. Terman. 1971. Nitrogen release from sulfur-coated urea as affected by coating weight, placement, and temperature. Agron. J. 63:529-533. 
Beard, J.B. 1973. Turfgrass: Science and culture. Prentice-Hall, Englewood Cliffs, NJ.

Carroll, J.C., and F.A. Welton. 1939. Effect of heavy and late applications of nitrogenous fertilizer on the cold resistance of Kentucky bluegrass. Plant Physiol. 14:297-308.

Hamamoto, M. 1966. Isobutylidene diurea as a slow acting nitrogen fertilizer and the studies in this field in Japan. Proc. 90. The Fertilizer Society, London.

Hanson, A.A., and F.V. Juska. 1961. Winter root activity in Kentucky bluegrass (Poa pratensis L.). Agron. J. 53:372-374.

Hughes, T.D. 1976. Nitrogen release from isobutylidene diurea: Soil pH and fertilizer particle size effects. Agron. J. 68:103-106.

Hummel, N.W., Jr., and D.V. Waddington. 1984. Sulfur-coated urea for turfgrass fertilization. Soil Sci. Soc. Am. J. 48:191-195.

Koski, A.J., and J.R. Street. 1985. Root growth and carbohydrate status of 'Baron' Kentucky bluegrass as affected by timing of nitrogen application. p. 118. In Agronomy abstracts. ASA, Madison, WI.

Ledeboer, F.B., and C.R. Skogley. 1973. Effects of various nitrogen sources, timing, and rates on quality and growth rate of coolseason turfgrasses. Agron. J. 65:243-246.

Lunt, O.R., and S.B. Clark. 1969. Properties and value of $1,1 \mathrm{di}-$ ureido isobutane (IBDU) as a long-lasting nitrogen fertilizer. $J$. Agric. Food Chem. 17:1269-1271.
Moberg, E.L., D.V. Waddington, and J.M. Duich. 1970. Evaluation of slow-release nitrogen sources on Merion Kentucky bluegrass. Soil Sci. Soc. Am. Proc. 34:335-339.

Powell, A.J., R.E. Blaser, and R.E. Schmidt. 1967a. Physiological and color aspects of turfgrasses with fall and winter nitrogen. Agron. J. 59:303-307.

- 1967b. Effect of nitrogen on winter root growth of bentgrass. Agron. J. 59:929-930.

Spangenberg, B.G., T.W. Fermanian, and D.J. Wehner, 1986. Evaluation of liquid-applied nitrogen fertilizers on Kentucky bluegrass turf. Agron. J. 78:1002-1006.

Volk, G.M., and G.C. Horn. 1975. Response curves of various turfgrasses to application of several controlled-release nitrogen sources. Agron. J. 67:201-204.

Waddington, D.V., J.M. Duich, and T.R. Turner. 1977. Turfgrass fertilization with isobutylidene diurea and ureaform. p. 319-334. In R.L. Goulding (ed.) Proc. 1977 Controlled Release Pesticide Symp., Corvallis, OR. 22-24 Aug. 1977. Oregon State Univ., Corvallis.

Wilkinson, J.F. 1977. Effect of IBDU and UF rate, date, and frequency of application on Merion Kentucky bluegrass. Agron. J. 69:657-661.

69.657 and D.T. Duff. 1972. Effects of fall fertilization on cold resistance, color, and growth of Kentucky bluegrass. Agron. J 64:345-348. 